\title{
Ángel de Campo and the Mexican Spanish of the 19 th century
}

\begin{abstract}
It analyzes the literary and journalistic work of Ángel de Campo (1868-1908) and the various phonetic, morphosyntactic and lexical records that appear in it both in dialogues and in the different narrative voices in order to see if its vitality continues in the Mexican dialect current or has followed other courses. The analyzed phenomena express the popular and cultured linguistic norms of the Spanish that was spoken in Mexico City at the end of the XIX century and the beginning of the XX, thanks to the record that the author makes especially of the marginalized social classes of the Mexican capital.
\end{abstract}

Volume 4 Issue I - 2019

\author{
Raúl Aristides Pérez Aguilar \\ Research professor, Mexican Academy of Language, University of \\ Quintana Roo, Mexico
}

\begin{abstract}
Correspondence: Raúl Aristides Pérez Aguilar, Research professor, Mexican Academy of Language, University of Quintana Roo, Mexico, Tel 529838350325 ,
\end{abstract}

Email rauperez@uqroo.edu.mx

Received: January 10, 2019 | Published: February 19, 2019

\section{Introduction}

The Mexican letters of the XIX century have in Angel de Campo one of the best exponents of the prosaic life of the beings that wander between the antrum and the suburb, between the desires to climb social steps and the problems of the cultural values that usually weigh more than the economic ones in a city that arrived at the 345 thousand inhabitants in the year of 1900 . This laborious life for the majority of the capital population is the frame in which the production is inserted Literary of Micrós (pseudonym used as well as Tick-Tack) whose characters have to show diverse records of speech accompanied by those of the own narrative voices that will explain the circumstances of their singular bustle in the neighborhood, the house, the store, the school, the canteen, the neighborhood, the trolleybus, and complete the descriptive pictures of the vicissitudes that pass not only human beings but beings not owners of reason (a canary called El Chiquito, a dog named Abelardo, a sweet called El Caramelo, some anonymous verses...), but also users of the Mexican dialectal variant.

If the nineteenth century"is poor, it is rustic, is literarily pathetic" by Sergio Fernandez ${ }^{1}$ because there is no great figures or geniuses that you have to follow or have innovated (respectable opinion or $\mathrm{n}$ literary scholar), the works-not all-that take place in this century do not show-it seems to me-lexical or plot poverty, but perhaps, yes of technique and also a certain rusticity in the speech of the characters (not of all), and this, in short, constitutes an achievement and not an error can characterize them with fidelity as speakers of the Mexican dialect ; Finally, they do not seem pathetic to me, and that is why you do not have to look at them with disdain. On the contrary, we must seek their value as products of a Mexican culture that is being transformed socially and that, for better or worse, establishment Porfirista, shows a social fabric of worm-eaten men and women, of abandoned children and women, of old and young who live on a daily basis, of lefty ruffians and leperos: the mob that will be the raw material of Micrós.

Another less emphatic opinion is that of José Luis Martínez who affirms that the 19th century in Mexican literature is a century in which there is an insistent search for a national expression-this occurs in the work of Micrós, mainly in the lexicon - that must combat the academicism of the previous century, confront and describe a convulsed and complex reality with great gaps between the bourgeoisie and the common people. And being the plebe this social reef for which Micrós takes sides, brings to the pages of their stories the hazards of their lives and what accompanies them and circumscribes: the desire to live away from the dunghill, the gossip of neighborhood, the patriarch machismo, submission of marriage for women, heroism, illness, child depravity, loneliness of prostitution, revenge, belief in immortal love, disdain for the environment, work of the sun a sun And not only this, he makes his characters talk and reproduces his syntactic turns, his phonetic anomalies, his patrimonial lexicon because it is not his eagerness to create beautiful texts but only to show a critical vision of Mexican society or those expelled from it. The plebe and his speech will be $\mathrm{n}$ fertile ground for Micros and she paid her wit not to social criticism, but to remove the bitterness, the dissatisfaction of those who live in the slum. His works: Leisures and notes (1890), Things seen (1894), Cartons (1897) La Rumba (1890-1891) published in 20 installments in El Nacional, his cheerful Weeks appeared from 19000 to 1908 in The Imparcia 1 and infinity of chronicles and scattered stories, they will be this fertilized field that will serve us as input to approach the speech of the Mexican Spanish of the XIX century, our modality that has not yet banished the use of you because it is still expressed with"those that you have loved" (jury of La Rumba) or"you see the children who approach their dad...", (priest Sanbenito of"White Souls"), who says:"and began to changuearme","he hit a glove to the girl" (witnesses of the trial of Remedios Vena, La Rumba), which contextualizes:" members lowered, the head was folded"(Narrative voice of" The death of Abelardo"). At least, in the Micrós literature, these uses of marked sociolinguistic differences appear. These are works of fiction, but credible for their plots, and more so for the records of popular speech they have among which we can find voices such as match, chrome, kite, chimixclán, chimiscolear, cacle, tinajal expressions as he poured plagues, then, later, on shirt chests or may be, daca, you're that currently are still alive (some) in the different social levels of urban and rural Mexico.

\section{Purposes}

Our goal is to show these records of speech extracted from the reality of the stories and put there thanks to the careful observation of Micrós, whose ear could capture the peculiar pronunciation of the Asturian benefactor 11 and love of Remedios Vena. But we will not only allude to the records of the popular speech of the characters, but also those of the narrative voices to see which are still valid in the XXI century and which have fallen into disuse for various reasons. We have to show the phonetic, morphosyntactic and lexical records that structure the narrative universe of Micrós, the universe of speech of the poor neighbourhood of the Mexican capital of the nineteenth century that usually extends to our days. We present each phenomenon with a quote like example of use- taken from each account, and the name of it and sometimes in context the scene, and the s consulted in the case of the lexicon; sources for the reader can resort to them. 


\section{The materials}

\section{Phonetics}

1. Bar"...barricade the door." "Births"

2. Afusilado"...a mob of boys shouted...El Chismito with the news of the afflicted!"'La Rumba.

3. Regina"Do I eat it? The regina..."chess player gift shop in Mauritius. La Rumba.

4. Malobra"- I find it malobra, Don Mauricio...!" Buyer Mauricio gift shop. La Rumba.

5. We are probes"...if we are you know, we have to stay..." elementary school teacher. La Rumba.

6. Leida,"I gave leida and escrebida, supposedly..." the same elementary school teacher. La Rumba.

7. Ecrebida,'I gave leida and escrebida, supposedly..."the same elementary school teacher. La Rumba.

8. Innorancia"...you are right, ignorance is the worst...", the same primary teacher, La Rumba.

9. Riumas"...the misfortune of these riumas that do not let me move." Porfirita to a young man, La Rumba.

10. Pray"-And pray?"...Pray everyone who scratches with their nails", shopkeeper. La Rumba.

11. Pos"- after what has Don Cosme to..."neighborhood woman. La Rumba.

12. Vide"...comadre, since I saw the gringo that nothing else..."neighborhood woman. La Rumba.

13. Dizque"...Pos dizque that Mexico went outside..." Smithy joven. La Rumba.

14. Usté”- Usté Yes, Don Mauricio...”, neighbor. La Rumba.

15. Mercé"...I wanted his service to give me a consolation." Mother of Remedios Vena. La Rumba.

16. Arismética”Requesting my arismética.”, Student of primary. La Rumba.

17. Tantiaba"...socormo not risked, like tantiaba..." neighborhood woman, La Rumba.

18. Chiquitilia"Since I was chiquitilia." Don Mauricio, the Spaniard. La Rumba with his peculiar pronunciation of 11.

19. Negocilio"I had a business." Don Mauricio, the Asturian. La Rumba.

20. Testerié"...threw me against the bed and with the iron...I tested myself here.'Remedios Vena. La Rumba.

21. Pior"...the milpas every day pior...", letter from Salomé Antonio"Portfolio notes".

22. Iduqué"...I did not write it wrong...", a rich and illiterate house servant who later says:"...but on Thursday I'm making a message..." "Portfolio notes"

23. Asidentes"Your daughter Petra is still bad of the asidentes, foams..., Salome Antonio letter addressed to this rich house maid.'Portfolio notes".
24. Buiga/Juerte"...no way to give it a pial so that it does not boil so you play" letter from Salomé Antonio addressed to this rich house maid."Portfolio notes"

25. Jaletinas"...the jaletinas, previously put to cool in their molds...", narrative voice of'The small table".

26. Jaletinero"...and jaletinero hawking their wares tiredly." Narrative voz of'The shot".

27. Pirú"...to the neighborhood of a pirú with his way of flying...", narrative voice of'El chiquito".

28. Juistes"OhAntonio of my life that you played to die!"'Brusquedad of the heating",

These speech anomalies appear exclusively in the mouths of the various characters of the texts, almost illiterate beings, people from the neighborhood full of precariousness, among which stands out a pronunciation that today seems rustic but continues to permeate the linguistic forms of Mexicans: pos, you say 'diste', you, pray, haiga, cafeses, algame' valegame', manesia, polezia, riumas, tantiaba, pader 'wall', jale 'gelatin', testerie, juices, vide, so much so the city as in the countryside. These prostheses, syncopations, apheresis, apócopes, confusion of phonemes, metathesis, monoptongation of hiatus give the peculiar note to these narrations because they are the living voice of popular speech. Some have fallen into disuse: vide, vido, mercé, escrebida ${ }^{1}$ although it is possible to hear them in towns and ranches and even in the city as distinct from a social class, not always precarious education: dijunto 'deceased', julano 'so-and-so', traite 'tra ete', voltié 'volteé', cafeses ' cafés', piedrada 'pedrada' venistes' came ', álgame! Válgame '...The forms jaletina and jaletinero, cover it, broken, bull Which are not quoted or italicized as afusilado, Piru,

'On the origin of this anomalous form it can be said that it is derived from the Spanish cult norm of the sixteenth century in Mexico, while Fray Alonso de Molina uses it in his Art of the Mexican and Castilian language in I57I: "La qual It has to be written with tyso with Tyzy, and it has to pronounce like tys saying ... "because Spanish was in an important stage of its evolution and the system was not yet fully stabilized.This voice and the like (escrebir, escrebimos, escrebiamos, escrebgo...) and s such $s$ the $s$ he heard the Indian who was learning Spanish and $s$ adopted and used in its various records speak for it constituted a fundamental part of its initial lexical heritage, as Lara ${ }^{3}$ suggests that occurred in central Mexico, and inherited his offspring. Thus, until the end of the 19th century in Mexico City, this use of escrebida, probably coined by analogy with read, as a multi- secular inheritance, especially in speakers with indigenous origin or inhabitants of a speech community in which the norm was to escrebir and does not write. This anomaly is also recorded in Mérida (Yucatán) in a text of 1558 collected by Melis: ${ }^{4}$... les dixe and a letter that they escrebi the hize depopulate..., and others in 1624 (escrevir), 1796(escrevir) as well as in Veracruz in 1568 (escreví, we escrevimos), in 1593 (escrevir), in 1734 (escrevi) in Conkal (Yucatán) (escreví), in 1609 in Hocabá (Yucatán) (escrevir), in Pánuco (Veracruz) in 1610 (escrevi), in Acayucan (Veracruz) in I637 (escrevi), in Orizaba (Veracruz) in 1675 (escrebir), in Papantla (Veracruz) in I78I (escrevi), in the Villa de Campeche in 1752 (escrevi), and in 1755 (escrevir). To be sure, its use (although it does not appear) became widespread, since 69 forms were documented by Company and Melis ${ }^{5}$ in Toluca in 1744 (escreví) and in 173I (escrevirá), in Mexico City in 1747(escrevía), in I578 (escrevirme), in 1575 (escrevjnos), in 1526 (escrevjr), in I57I (escrevís) and in 1574 (descrevir) without place of origin. The same can be said of the forms Vido and Vide which are documented in Melis: ${ }^{4}$ "... any person aya saidVido do or aya done ... as well as Company and Melis ${ }^{5}$ in the City and Mexico in 1529 and 1689, in Puebla in 1697, in Patzcuaro (Michoacán) in 1689 and in Yolotepec (Hidalgo) in 1739. Similarly happens with the form adevinar (which does not appear in Micrós but heard by this author in Mexico City of an almost illiterate older man) and used by Andres de Olmos in Fray its Art Mexican language ... and ANSI in it we have to walk adeuinando; but..." 
that"haiga""encompadrear" and other narrative voices and charactersprove that, in the late nineteenth century, use was shared by all standard $\mathrm{s}$ in Mexican society because these voices of the narrators are closer to that of the author than to most of the characters created by him.

\section{Morphosyntax}

Several are the morphosyntactic phenomena that evidence the stories, many of them in the mouths of the characters or in certain passages of the narrators are symptomatic of the Mexican Spanish of the 19th century in the capital of the country; Colloquial, popular, cultured forms are mixed in these stories that today seem strange to us, although many of them are still used in more or less formal situations. There are numerous cases of the use of it are like enclitic:"mouldering on the swarm there stood","...contábase it was albe to argue of the people..." "But came the afternoon, calmábase the heat..."“"A whimpering, golpeábanse other and..."“He remained Remedios alone..."," he grieved girl..."

All used by the narrator of La Rumba in narrative and descriptive segments, and never appear in dialogues between the characters. This unusual form of speech seems to be more typical of written language and fashion, or a characteristic norm not only of nineteenth-century Mexican literary fiction. Of more colloquial court are: the disgust, 'scolded', memories to the Lord 'greetings to the Lord', then, then 'immediately', walk throws a banderilla 'walk adorned the woman', dress die 'dress with clothes used as a gift ', give yourself a vidurria " give yourself the great life ', That's why nca advance you ' why you never progress', I have no field to come 'I have no opportunity to come', it is known that it does not reach the shirt body 'is that you are very afraid', - will you $\mathrm{r}$ c hupa ${ }^{2}$ a cigarette ? Said the mother...'Do you want to smoke a cigarette?'...Supposedly had collected but evil tongues say that was not a collection but the daughter of Dona Maria are you approaching? 'Do you understand?' Mialma 'my soul' Mija 'my daughter', saying it was violentit or 'saying it was soon', Quese "what was done, where is'"-hay and Quese frost ?, dequen 'den here',"Deque the palace of Herod!","- Daca ${ }^{3}$ the umbrella"'go to the umbrella'," - Déque that"' give me that', haiga " haya ', encompassrea $r$ 'encompadrar', blow the helmets to someone 'flirting someone', like a donkey without mecate 'walk freely, no strings attached', remind primer 'remind them of their obligations to someone', and chole 'sign of pain or discomfort', I figure no pineapple 'no chance of wooing a woman', we leave this size 'dícese the state it stays or concludes a matter', I remuerto without pelican of doubt 'dead without hair (with nothing) of doubt ', palanquéale " palanquea ', do not sparkle ' that is not going to fall or lose ', each one falls with his quota' each one cooperates with money for something ', stay eleven ' to be surprised ', nowadays in Mexico it is used to stay for six 'quedarse de a seis'.

Possessive doubling usually appears in the mouths of the characters as unique feature of the plebs speech:"...Dona Maria, her comadre you..."“'Doña Chole","...his father you already have to go through the tandas."' The petates"," Few are the people who, like your uncle of you..."'Judas Factory". On the other hand, the diminutives are numerous both in the characters and in the narrative voices:"What I want is a little saint...Look at that little horse, do you see what a pimp? Well, look at the little machine...The little soldiers, do you see what pimps??...Because you're sick, nana from"The boy with the blue glasses"."...Giving nervous jumps on the cobblestone...jump from the stick to the filthy floor..." narrative voice of'El chiquito".....and

${ }^{2}$ Form documented in 1689 in Mexico City.

${ }^{3}$ Documented in 1815 in Mexico City. ${ }^{5}$ other older ones, wounded...and the good educadito Ciprian...In the young used to..."narrator of"The table girl."“"That little orgule has to spoil you, because of your little love to treat one...give me a little water, cool.", Gualupita, friend of Remedios Vena."...but he wants to walk in a ball with those of the tapalito and the little botincito..." narrative voice of La Rumba. All of them used not only to indicate the size or quantity of the referent or the phenomenon, but to indicate various pragmatic valuations that the speaker projects on them, ${ }^{6}$ and in that sense it is a proper use of Mexican Spanish whose speakers (characters and narrators in this case) seem to be more interested in offering"their vision" of reality and not just describing it as it is. The following examples they show this peculiar use:" Tempranito lights his twisted candles." "The births","...each of us carries his little novel on his head..."“From the national novel","...and the years make it discolored and rotita."' blanket","...are already retinues the largest"the cuetero of" Factory Judas","... asking for a little father to confess to a person..."”'Old verbenas","...a jug for atolito..."El jarro."”...la lavandera por nadita does not bring shirts."' Poor Jacinta!"

\section{Lexicon}

This line is the richest from the linguistic point of view because it puts on the table the use of idiolectales voices of the author (not only in the narrative voices) and the colloquial (not only in the characters) mixing them in the stories according to the subject and the circumstances in which descriptions and narrations are inserted. These voices give a touch of verisimilitude to the stories and show a deep Mexicanism typical of a man who was born and raised in Mexico City, who was abroad-something left in his cultural heritage-but who returned to his homeland to write about him and leave us the records in his literary writings. The studied voices are presented in alphabetical order followed by the sources consulted and an example of use in the stories and chronicles. Some are not documented either be creating MICROS (osculizar, voluptosear) or lack of lexicographical studies that record. Accessoria piece or room that is part of a building but independent of it, with its own entrance from the street, is often used as a commercial space. "'You'll see," the mother shouted from the accessory. La Rumba. The voice has been documented since 1695 in Mexico City. ${ }^{5}$

Acocote 'gourd or guaje in the form of a long and narrow pipette, hollow and punctured at both ends that the tlachiqueros use to extract the honey from the magueyes, applying the lips and sucking it'. Etim. atl 'water' and cocotli' gargüelo'.."...mayate like a acocote"“The dangers of El Grito". Accion 'informal raffle number'. It's worth two real shares." "Doña Chole."Aindiar 'to resemble the Indian in factions, manners or customs'. ${ }^{8}$ "...she is the mother of the figurines and even more, her maid." Axolotl aquatic animal, batrachian of dark coloration as of 20 centimeters long and disgusting aspect. Etim. Axolotl 'water toy' of atl 'water' and xólotl 'toy', DAz."...of the axolotl enraged by three hundred fleas on an empty stomach"“"El taimo de la tarasca". Albur 'a certain game of cards', DMej."...you earn albures of monkeys with swords"“Brusquedad of the heating". Alegría "very common candy that is sold at fairs and that is made by mixing the seeds of the plant of the same name (Amaranthus pediculatus) with boiled piloncillo. It is also called huautle', DMej."...I rub shoulders with the nuggets, toast, beans, chickpeas and arbejones, the joys and pepitorias..."“"The caramel"

Altero 'pile, overcrowding, conglomerate of things that have great height or that is greater in that dimension', DMej."...between an altero of empty tompeates..." La Rumba. Antro 'room or closed place that 
produces displeasure or repulsion for being unhealthy, dark, narrow, etc ‘, DEM."'Gualupita He looked out at the den that used to be a room." La Rumba. Arrancado "It is torn from the subject that having had goods of fortune, he loses them all and remains helpless,"DMej."For the ripped off that is another moral danger..."“'Other moral dangers of public roads" Arranquera 'lack of money, usual or temporary', DMej.".. this perpetual and invariable sign: chronic outburst" "Graphology" Atajo 'recua, small group of animals that have separated from the herd', DMej/DEM.'No wonder the rest of us seemed like a shortcut by Indians..."“"El Chato Barrios" Atole "thick drink that is made with flour or corn dough and cast in a sieve and then boiled to give the consistency of porridge or polenta'. Etymology: atl 'water' and tlaoli 'ground corn', Diccionario e aztequismos (hereinafter DAz)."... another vessel destined to the white atole." "The ancient festivals" The voice has been documented since 1550 in Mexico City. ${ }^{5}$ Atolería 'place where atole is made, and where it is sold', DMej."...or from the interior of suffocating atolería..."“Electric light, asphalt and new nomenclature". Atorzonar 'to get sick from meteorite', DMej."...the day the Lord got tormented, I swear..."'Genesis of the crime"

Ayate 'thin blanket woven with ixtle or maguey fiber, which is used to wrap and load something'. Etymology: áyatl 'manta rala'. DAz.”...and in a ayate I spilled some wheat." La Rumba. Bachicha 'cigar butt cigar, pure rope', DMej. It is also 'the stool or seat of liquor in the glasses in which it has been drunk, the leftovers of the dishes in which it has been eaten'. Etim. Hi Pachic'restos', Daz."...trimmed and quasi- bacchicha for the conservatives..."'In defense of the cigarette." Baratillo "unique market in its kind and in which old clothes of all kinds are bought and sold', DMej." Jicareros and sellers dressed in scraps of baratillo" "the noises of Mexico" Barbacoa Voice possibly taína, DLE. 'meat, generally of sheep or goat, which is cooked together with chopped vegetables and chickpeas, covered with banana or maguey leaves, in a hole in the ground whose bottom is covered with previously heated stones', (Diccionario de mexicanismos, hereinafter DM)."-You forgot the barbecue tacos and the..." "Disadvantages of the swine regime". Beberecua 'generic alcoholic beverage, which likes to drink alcoholic beverages in excess', DMej."...gave him for the baby and to fall..."'Homemade."

Billete 'remiendo, or piece of cloth that is sewn to what is old or broken ', Lexicographical Treasure of the Spanish of Puerto Rico (hereinafter TLEPR),"Removed the glasses, cleaned them with a ticket..." La Rumba. The voice has been documented since 1691 in Mexico City with different meaning. ${ }^{5}$ Birote' white bread made of wheat flour and salt, its shape resembles cones opposed by their bases and ends in two nipples at their ends, about 15 centimeters long, soft and spongy on the inside and brittle on the outside', DM."-Two birotes, a pambazo and..."“'Idyll and elegy" Bronca 'quarrel, pendency and even for dispute, batahola, lagazara', DMej."....and in the first row they take a tassel..." The famous raspa". Buir "boil in the sense of moving with agitation mainly the rider to the horse', DMej, it is used in the sense of 'to animate, to excite, to move'. ${ }^{9}$ Do not buzz, it's used to tell someone to stop talking or meddling in an issue, DM."... so that it does not bounce so much..."“Portfolio notes". Bule (voice cahíta) "pumpkin, güiro that is also called guaje. It is the Mayan lec 'DMej."...that in her, even with bules, she is afloat"."Pane". Busca "profit, usually illicit, which is derived from a job or position mainly of a public nature', DMej."The searches have become a natural thing, that..."'Out of the box". Cocoa 'the almond or fruit of the cocoa tree from which the chocolate is made and which in pre-Cortesian times was used as a counting among the Indians', Etim. cacaohuatl 'cacao'. DAz."...Coffee, cocoa cream..."'Disadvantages of the swine regime".
The voice has been documented since 1525 in Mexico City. ${ }^{5}$ Cacique 'ruler or chief of a community or town of Indians', DLE, 'despot, tyrant, arbitrary, bossy', DMej. It's a Caribbean voice....often clashes with the purebred cacique..."The birthday of Lola Erizo and Trebuesto in the Paseo de la Viga". The voice has been documented since 1525 in Mexico City. ${ }^{5}$ Cacle 'footwear, simple leather sandal consisting of a sole and a strap that holds the carcass and passes between the big toe and the second finger'. Etymology: cactli 'footwear', DAz."... with the fight hat and the heroic cape,"“The blanket" Cacomixcle or cacomiztle or camixtle 'Basáride, mammal butcher, which causes a lot of damage in the bird pens'. Etymology: tlacomistli 'half lion, half cat, DAz."...and the cacomixcle is around and has already eaten some chickens...""Portfolio notes".

Cachimba 'smoking pipe', DMej."...what in all those venerable nations is burned in hookahs." "How we smoke!" Cachivachero 'person who gathers odds and ends', DMej."...the junk dealer, the junkie...ro...ero..." "In the narrow gauge car". Cachote "vulgarism of the French cachot ' dungeon ', DMej."...to the cachote, that dark and damp room..."“Poor old man!" Cafre 'zafia y rústica person', Dictionary of the Spanish Language (hereinafter DLE)."Stood up a kind of kaffir eight years old..." La Rumba. Caliche 'lime on the wall', DMej."...if at that age a girl licked the walls eating caliche" "Disadvantages of the swine regime". Callista "person who is dedicated to cut or remove and cure corns, fingernails and other diseases of the feet', DLE.'Just by writing your diary a callist to, by note, you would become rich by the novelty of your impressions."' Of the national novel" Cambalachar "exchange things, objects'" DMej...a dirty stamp to exchange it for a sharpened pencil with a knife..."' The pointer and the soldier". The voice has been documented since 1731 in the State of Mexico. ${ }^{5}$ Cambaya "ordinary cotton fabric, is cloth used for workers' and peasants ' clothing, DMej."...wads, cambayas and chiquihuites..." Merry week The english language and mexican bussines". The voice has been documented since 1731 in Toluca. ${ }^{5}$ Camelar 'see, look, stalk', DMej."...A drunken guy insulting men, harassing women..."“Notes on Perico Vera"

Canuto 'sorbet of milk, egg and sugar that curdles in cylindrical molds and remains in the shape of a tube', DMej."...the lawyers tasted the pineapple canutos..."“The Mexico that disappears. The Concord". Canoa. Voice taína 'rowing boat or pole, very narrow, sometimes made of wood in one piece, is used mainly in rivers and in the practice of boating', DEM.'Dispute between the admirals of the canoe..." "The birthday of Lola Erizo and Trebuesto in the ride of La Viga" The voice has been documented in 1525 in Mexico City. ${ }^{5}$ Capirotada 'dessert of sliced and fried bread, bathed with piloncillo honey, cheese and peanuts', DM."... and from the hospital to the capirotada!".'The cooks and daily life". Capirote "old hood with skirt that fell on the shoulders and sometimes reached the waist', DLE."...where there is no hood is awning, where..." "The blanket" Capulin "tree of the family of Rosaceae, whose fine wood is used in cabinetmaking and produces a small cherry species of dark, almost black color. Etim. capulin or capolin 'cherry', DAz."...That produces with laborious labor a few capulines..."'Out of sentry box". Carnitas "pork chopped and fried in its own fat', DM."...the fat ones, the carnitas..."“'Disadvantages of the swine regime" Catalan 'aguardiente', DMej."...cloudy glasses with two fingers of Catalan..." "The Mexico that disappears The Concord" Cartucho 'cylindrical paper wrap', DMej."...or buy an almond cartridge..."“'Sunday." The voice has been documented since 1796 in Oaxaca. ${ }^{5}$ Cerillo " voceador of news, of the hour, of the lottery'.....The sellers of newspapers and matches shouted..."'Small Prose" 
Cilindro 'organillo', DMej.”...and fragments of polka crushed by the handle of a street cylinder:..." "The ancient verbenas" Cocol "bread wheat flour or corn, kneaded with honey to which sele rhomboid shapes'. Etymology: reduplicative cocóltic of cóltic 'twisted', Daz."...There you are offered with a glass of cocoles..."“The ancient verbenas" Comal "disk cooked in clay as a half meter in diameter slightly concave that is used to cook corn tortillas, toast beans, coffee, etc, putting it on the tenamaxtles' rough volcanic stone' of the tecuil 'rudimentary stove'. Etymology: comalli 'name of said utensil in nahoa', DAz."....and the child was crawling around holding an omelet made from the comal..." "The death of Abelardo" Coyote "color that is classified similar to that animal, rebozo of the color of the coyote', DMej."...to the poor lady of the rebozo coyote who..."“Portfolio notes". The voice has been documented since 1772 in Jalisco. Cromo 'colorful illustration printed on printed paper', DEM."...the cards of a doraduría" "Caifás and Carreño" Cuaco "horse', DMej."And the cuaco the paleros were loaded" "The blanket" Cuatrapeado "that is not in its place', DMej."Gentlemen, please get off to get on the car, it's quatrapped."'In the narrow gauge car". Cucurucho 'cone or funnel that is formed by rolling a sheet of paper, newspaper, etc., to contain seeds, wrap weeds or flowers, etc, or that serves as a hat', DEM."... the clerk removed the cones that protected the lamps from the dust and....'La Rumba.

Cuelga 'It should be noted that in Mexico it is said of the 'gift that is made not only on the day of the birthday, but on any date and with any fausto family motive ', DMej."Goodbye hangs, tarascas, noisemakers, bowling, bonuses..." Congratulations and charges in passing on the occasion of the new year." Culantro 'cilantro'..'..I was coming to see if they were showing him a twig of coriander." "Poor Jacinta!" Curado "pulque that has been mixed with juice of some fruit', DM."...the imposing curing vats..."“The ancient verbenas" Chafarote 'big and ugly knife', DMej."...daggers, bullies..."“El jierro" Chagüixcle or chahuiztle "parasitic disease of various plants, especially cereals'. Etymology: chiáhuitl 'humor, humidity' of quiáhuitl 'rain', DAz."...we have dropped the chagüixcle..."“Portfolio notes" Chalupa " tortilla de maíz, small and thick, oval, usually curled somewhat toasted and with some seasoning inside', DMej."...stains tablecloths, refried with chalupitas..." "Disadvantages of the swine regime" Changarro "tendejón' "...the so-called changarros and other places of consumption..."'Da capo al signo". Changuear 'joke', TLEPR."And he started to get me started..." La Rumba. Charamusca "confection in the shape of a corkscrew made of ordinary sugar or sugar, mixed with other substances and caramelized', DMej."...under the table and with a timid voice, a charamusca..."“The candy"

Chaveta/charrasca knife, spent weapon, laminated and sharp by the compun of tin. It is the own weapon of the pelado', DMej."... chafarotes, charrascas..."“"El jierro” Chicha 'alcoholic beverage resulting from the fermentation of corn with sugar water. Etymology: chichatl 'fermented water', from chichía 'sour a drink' and atl 'water', DAz"...shaking chicha barrels..." La Rumba. Chichicuilote wader, small, legs and long beak Etim. tzitzicuílotl de tzitzicuíltic "very skinny' and huílotl 'paloma, DAz."...the chichicuilote attached to a cart of cardboard." "Notes on Perico Vera". Chiflón "untimely air stream passing through a place especially narrow particularly in a building or a house', DM."... of wind and a conflict of chiflones..."“Behind the curtain". Chilaco/chilaca "variety of very hot, thin and small chile that remains green in maturity', DMej Etim. apócope of chilacate of chilli and ácatl, Daz."...to take a humble breakfast with refried chilacos and tamales..."“The ancient verbenas". Chile 'ají de las Indias, pepper or fruit whose spicy flavor makes it very used in Mexico to make or flavor a large number of regional dishes'. Etim. chilli 'chile', DAz."You forgot the barbecue tacos and the stuffed chilies" "Disadvantages of the swine regime". The voice was documented since 1526 in Mexico City. ${ }^{5}$

Chiluca 'trachyte amphibole, stone siliceous dark green or rosagris that easily styling and is used for building and pavement'. Etim. chilucan or chilhuacán 'place from where this stone was taken', DAz."Of chiluca and not of marble you deserve your truncated pyramid..." The death of the small gender and the day of the finados". Chimiscolear "comadrear walk from house to house in search of parties or meetings or a fondness for gossip'. Etim walk asking for a drink that is the Castilian form of chimiscol that is 'a drink of pulque or aguardiente' <corruption of xiniti, xin-ixcolli 'takes a drink', DAz."...two ladies (bench and rosary) chimiscoleaban on the gossip of a comadre..." "At last we have time..." Chimixtlán or chimisclán 'a bread made with piloncillo honey, in rombiodal form, that is to say of cocol, without varnish of egg white, nor sesame', DAz. Cabrera ${ }^{10}$ says"'I've never heard this word used outside the well-known song or song that alludes to the pride of those who have changed their fortunes:" Oh, cocol, you do not remember when you were chimixtlan, and now that you have your sesame, you do not want to remember me anymore"And he adds that it is an unknown etymology. Probable corruption of químic patlan 'bat', or maybe it was the bread of the chimiscoleaban. Chimolera corruption of chilmolera 'woman who makes or sells chili dishes and other similar dishes' derived from chimol or chilmole, Etim chilli and molli 'chili stew', DAz."...chiimoleras stir their fried..."“Pane." China "woman, formerly companion of the charro, dressed in general in a very characteristic way, with bright fabrics, bright colors, embroidered olans with sequins and rebozo', DEM.”...if you have the Chinese woman who has sworn to spend in candles..."“El jugro". The voice has been documented since $1682 .{ }^{5}$ China 'curly eyelash'."Do not take away your fondness / Black with Chinese lashes"“The blanket" Chinampa 'short terrain in the lakes of the Valley of Mexico where vegetables and flowers are grown'. Etymology: chinámitl 'weaving of branches or reeds' and bread 'on top of', DAz."Those are fertile chinampas of pictures." "Factory of Judas" Chinampina " hustler', DMej."...the notary's children lit chinampinas."“Poor Jacinta!" Chinguiñoso " legañoso ', DMej.”With those chinguiñosos eyes..." "The license" Chinese "hair curl"....many Chinese on the forehead and sideburns..." "For San Ildefonso." Chiqueador 'slices of grass soaked in some medicinal substance that sticks on the temples as a home remedy for some discomfort, DM."...at the temples, a chiqueador of chewed herbs..."“On the plains"

Chiquihuite 'basket or wicker basket almost cylindrical shape and a little narrower in the part of the seat than one on the edge'. Etim chiquíhuitl 'basket or basket' DAz."...wads, cambayas, and chiquihuites..."“Merry week. The english language and mexican bussines". Chistar 'to say nothing, not to protest', DEM."They did not sing a word, they covered their mouths..." La Rumba. Chocolate "drink made from cocoa, the paste to make that drink made of cocoa, sugar, bread crumbs, and some other flavor, especially vanilla or cinnamon', Etim. xocóatl 'acid water' from xócoc 'acid' and atl 'water', DAz."i A chocolate with chimisclán!"'“The Mexico disappearing. The Concord" The voice has been documented in 1621 in Mexico City. Chocho 'sugary homeopathic pill', DMej."Here they are, Nene, I thought they were chochos." "Future of the posadas". Chongo "sweet that is made of curdled milk and syrup' DMej."Do you believe that the Queretan chongos have been the toxic substance...?"“'Genesis 
of the crime." Chorcha 'group, gang of young people rejoicing and maleante', DMej."It was a little raspberry..."“The famous raspa". Desteloscopiar "discover" "The gendarme deteloscopía a package that lies on a bench..."“"Laps through the socket".

To delay 'delay, delay someone', DM.”...You are going to look for me at the theater, do not delay..." "The citizen Gestas". The voice was documented in 1554 in Mexico City. ${ }^{5}$ Doraduría 'store of frames, articles for artists, works of art, wallpaper, glasses, crystals, moons, cards, etc. '“...to all the portraits of a photograph or silently admire the cards of a doraduría."'CCaiphas and Carreño.” Drug 'debt', DMej.”New drug for what was bought on credit" "La call eprivada". The voice has been documented since 1692 in Mexico City. ${ }^{5}$ Castor "vainglorious, braggart, boastful; that promises what he does not have to fulfill; that flaunts power, wealth or clothes that do not have ', DMej."Farsante !, miser !, echador !"'“The death of the small genre and the day of the finados". To throw raspa 'to make shouts, to joke, to stir up ', DMej."...and they are throwing scrapes with young girls with white combs..."“The famous rasp". Petticoat "Woman's garment covering from the waist down', DEM. It's a Taino voice, DLE"...put on shoes, the purple petticoat..." La Rumba. In the form naguas 'petticoats' was documented in 1694 in Oaxaca. ${ }^{5}$ Enchilada "corn tortilla seasoned with chili, onion, cheese etc ', DMej."...Others ordered several plates of enchiladas..."“The old verbenas" Surrogate 'indebted', DMej,"A: No, drugged that is worse." "God raises them..." To be silly (to) "to be angry, to be afraid, to be sullen', DMej." How is enfullinaba when the stop is one cocky."“Poor man!" Equipal "chair with backrest made of rattan or wicker in the shape of an armchair and usually lined with leather on the seat and on the backrest'. Etymology: icpalli 'armchair or throne', derived from ícpac 'above'. DAz."...A tallow candle in tin candlestick on equipal...” La Rumba.

Escamocho 'leftovers, but only of food', DMej.”..., garbage, debris, chubby and other..."“Asphalt electric light and new nomenclature." Escolapiar 'do or dec go own things of the Piarist', DMej."...and that is why I was escopling you." "Street love and balcony life". Escuchillada " something snorted, stabbed, pierced " "...the underskirts with less cloth and more squeezed than a coachman's umbrella."'On the plains" Escuintle or escuincle 'skinny street dog'. Etymology: izcuintli 'a kind of bald and dumb dog that the Indians used to eat to eat', DAz."There was an aristocrat under his sheepskin of vulgar and street escuintle"“The death of Abelardo"

Estanquillo 'store of short and even very short capital where cigars, cigars, matches, lottery tickets are sold, and in many there are also silks, yarn, stamens, ribbons, dolls, toys and countless other trinkets', DMej."...his mistress, who was the owner of a stalemate and had..."“"El pinto" Evangelista 'memorialist, clerk who in a stand earns scarcely life writing letters or other papers needed by the people of the town who cannot read or write', DMej."...the tinterillo or the evangelist, or to have him cut..."“Los petates" Faceta "funny but affected and without grace', DMej."...women are very facets and novelists." "Disadvantages of the swine regime". Figurine "garment fashion catalog', TLEPR, generally contain sewing patterns."...mixed with elegant fashion figurines."“History of some verses" Gabacho 'that is of white skin and blond hair, that is güero', DEM. 'French', derogatory, DLE.”El carrero: Poor gabacho!” La Rumba. Galero 'in the language jailer, guardian of cell, in prison, as well as the catwalker is guardian of door', DMej."...and they are taking them out of the chapel and the galleries shout: So-and-so!" La Rumba. Galopina 'woman who helps the cook in her work', DMej."Fifteen pesos in advance, galopina, ration..."“The menegilda." Gallito " swirl that forms in the head of a person', DM."...When someone was stopped by a cock."“'Poor old man!" Gandul 'Indian barbarian', DMej."...from among arises kill a wastrel, half Indian, half azafranado"“It s plains"

Garnucho blow that occurs with the middle finger after holding it with the thumb DLE the DM registers the garnuchazo form."... why did he give us little holes in his ears?"“Poor old man!" Garrote "carriage brake', DMej."...difficult company to give them and take away the club..."“Juvenal." Dar garrote 'apply the brakes on the wheels of the carriage', DMej."'If the gentleman the other day, who could not give cudgel..."“'Impressions of motorsport". Gendarme 'guardian, police officer in the cities', DMej."...Do not suspect the gendarme or have blown up the report." "On the plains" Gorda "corn tortilla thicker than usual and stuffed with pork rind', DM."...the quesadilla, the fat ones..." Disadvantages of the swine regime". Guajolote 'turkey' (Melleagris gallopavo), DMej."...when a turkey is greeted with targets..." "The birthday of Lola Erizo and Trebuesto in the Paseo de la Viga" Guamazo "slap, slap “, DMej.”...with whoever looks at it ugly and gives of guamazos..."“The dangers of The Scream". Guarache 'sort of coarse leather sandal', DM. It's purepepecha voice, DAz."... Muddy guaraches." La Rumba. The voice has been documented since 1630 in Puebla. ${ }^{5}$

Guayabate 'sweet paste made from guava, and usually arranged in parallelepipeds. Peculiar industry of Morelia', DMej."Julia sends you this basket of fruit; these guayobates Uncle Andres..."'Small Prose" Guayín 'light carriage on the road, four wheels and as many seats, closed with leather curtains', DMej."...the dairy guayines..."“The noises of Mexico" Hacer el oso 'gallant, hover and conquer a woman'."...so many handsome men who made him the bear and went to meet Cejudo".’Poor Cejudo!" Hacerse guaje "pretend silly or distracted'. Etim. huaxin 'the guaje tree', DAz."- You do not make me guaje ?"“Back!". Huacal 'kind of angling or box formed of wooden rods arranged in the shape of a huacal (two rods plus two overlapping transverse rods) and tying the parts of the crossing and used to carry fruit or crockery or any other fragile merchandise.' Etymology: huacqui 'thing seca' and calli 'casa', DAz."...A moving crate..."“The noises of Mexico" Huizache 'species of acacia, very thorny plant of the legume family'. Etymology: huixachi 'thorny tree' of huitzli 'thorns' and ixachi 'in quantity', DAz.'...a dwarf huizache, to which they have..." "On the plains" Itamo 'voice formed maybe by corruption of dictum. Plant with flowers that look like red and yellow vejiguillas and containing medicinal sweetened juice as an antidiarrheal and for the affections of the throat and chest ", DMej."...A box of cigars and three glasses of refining with ítamo..."“By the plains"

Jacal 'hut, humble house, almost always made of adobe and thatched roof' Etim. zacalli 'hut', xacámitl 'adobe' and calli 'casa' or xalli 'arena', DAz."...of an almost vegetative life in the primitive jacal..."“Out of sentry box".

Jagüey 'artificial deposit of water in the land or temporary deposit in the field' Etymology: from the Maya has' 'water' and uay, uaye 'here', DMej."...staining the waters of the jagüey where half-naked women washed..." Small Prose Jamaica sort of charity sale that is held to gather money with some generally pious purpose; popular festival, verbena DMej"They went to the examination as a jamaica."“Shadow of Medrano" Jarano "felt hat with a tall, wide brim, usually lined with a lace topped with tassels', DMej."...wide hats of discarded palm, jaranos of worn chevrons..." La Rumba. Jeremiquear 'whining, whining, crying, hiccuping', DMej. No sir, (jeremiqueando) the other! 
Poor old man! Jícara 'vessel made with the epicarp of certain creeping plants belonging to the cucurbitaceae family'. Etymology: xicalli "jícara', ${ }^{11}$ "...nor the jícara where to pour the liqueur of friendship." "El jugro". The voice has been documented since 1694 in the State of Mexico. ${ }^{5}$

Jicarero person who takes care of making, painting and embroidering jícaras or cultivating them DMej"jicareros and porters dressed in scraps of" The Noises of Mexico" Joloche "shell opaja covering the maize cob'. Eti. of Maya holoch 'shell', DMej.".. This one with your sheet frills..."'In defense of the cigarette". Juil 'small fish from the waters of the Valley of Mexico'. Etiim. xohuilin 'a fish that looks like trout', DAz."...corn leaves burned with rest of juiles..."“The lépero". Jugar volados 'act of throwing a coin in the air to decide, between two options, according to the face that is above', DM."...plays ruffled among the herbs of the pantheon..." Notes on Perico Vera." Lagartijo 'lechuguero, pisaverde, petimetre, catrín, lazy, idle who is always well dressed', DMej."...This pusillanimous and sick liver lizard..."“The rented housing." Leopoldina "pocket watch chain, pending of this one, short and of which usually hangs a medal, shield, etc. It is worn in the pocket of the pants', DMej."...favored by fortune, with a leopoldina, a small bag..." "The dangers of El Grito". Lépero 'a wicked person and montonera that adjoins the ruffian'. ${ }^{12}$ "... the evangelist is the secretary of the leperos, the confidant of the rabble..." "Portfolio notes". Maguey "plant of the amaryllidaceae family and almost all of which produce fiber or juice for spirits', DMej. It's the Arawak Caribbean voice, DAz.”...far away behind the magueyes..." "On the plains" The voice has been documented since 1694 in Oaxaca. ${ }^{5}$ Malobra ' made molest to or harms a person' DM."Do not make me bad, go to your chore."“Ididlio and elegía" Mamey ' caribe voice', DMej, "fruit of that tree, almost round, of brown, thin and porous bark, pulp of orange color very aromatic and sweet taste and with seed in the shape of kidney', DM"...mamey, orange, nuts of Castilla..."'Disadvantages of the swine regime".

Mano 'brother, carnal'“-Really, hand? La Rumba. Matatena 'cinch consisting throwing a handful of pebbles receiving few possible on the back of the hand, then gorec or giendo which fell to the ground one by one, throwing up another pebble, while collected one of the fallen ones'. Etim. maitl 'hand' and tlatema 'throwing pebbles', DAz.”...play pairs and nons with the matatenas not to get annoyed..."'Make the bear". Mayate 'multicolored and bright flying beetle, coprophagous, which makes small balls in the excrement to deposit their eggs there.' Etim. máiatl 'true beetle that flies'. DAz."...mayate as acocote."“'The dangers of El Grito". Mecapalero "mozo de cordel, loader that uses the mecapal to load'. Etymology. Derived from mecapal, from mécatl 'rope' and palli 'ending that denotes wide or flat thing' ', DAz."...a hireling hired as a beast of burden..." "The ancient verbenas" Mecate 'cord or rope made from maguey ixtle or other hard fiber', Etymology: mécatl 'cordel or rope' and metl 'maguey', DAz.”...small table with rope, distiller..." "The noises of Mexico". The voice has been documented since 1694 in Oaxaca. ${ }^{5}$

Memorias 'greetings s " "And memories to all for your house"" Responsos". Menudo 'morralla' Lexicographical treasure of Canary Spanish (hereinafter TLEC)."...the tenates full of often..."“The citizen Gestas" Metate "rectangular stone slightly concave, with legs, one end higher than the other, on which are usually milled with metlapil corn, other grains or any generally dry food', DM. Etymology: métlatl 'stone where corn is ground', DAz."...sitting on his heels in front of a metate..." La Rumba. Mezquino "wart that leaves in the hands or feet, very painful to tear', DMej."....as the petty on a maiden's finger is cut..." "The jierro" Milpa 'sowing or planting corn'. Etymology: milli 'sementera' and bread 'on', DAz."...the cornfields go every day pior..."“Notes portfolio". The voice was documented from 1630 in Oaxaca ${ }^{5}$ Mollete "piece of baguete or bolillo split lengthwise, heated and smeared with refried beans and covered with cheese gratin on the top', DM."...your big cup of coffee with milk, with muffins and tamales." "Disadvantages of the swine regime". Morillo 'stringer or wooden beam, resting on beams that rest on brick columns and on which are nailed boards that complete the roof of rustic constructions, usual in the center and north', DMej."...They were traveling long packloads loaded with buttern and..."“Pane." Morlaco 'the one peso coin, mainly the silver one', DMej."...they pocket the morlacos and half..."Architecture". Muina 'anger, anger, annoyance'.....the poor thing was killed by my compadre muinas..."“Portfolio notes" Neutle 'name that the low town gives pulque in Mexico'. Etim. necic 'sweet thing' and octli 'wine', DAz."...bread, neutle and cigars are offered..."'In defense of the cigarette".

Nopal 'cactus plant with large, oval leaves in the form of fleshy leaves bristling with thorns'. Etymology: nopalli 'nopal', DAz.”...and they raised their large spiny dusty nopales leaves." "Gladiator." The voice has been documented since 1694 in Oaxaca. ${ }^{5}$ Ocote 'resinous tree with filiform leaves of the family of the conifers or abetinaceae'. Etymology: ocotl 'tile, slit, sliver', DAz."...and the ocote smoke from the fires." "The births." The voice was documented since 1694 in Oaxaca. ${ }^{5}$ Osculizar 'kiss'."...That in the mere noses of the gendarme are hidden..." "Street love and balcony life". Otate 'reed strong and strong that is the cane. Etim. otatli 'hard cane' from ótlatl 'solid and strong cane', DAz."...and my name brandished the touch, an otate."'Street music." Paliacate "large handkerchief of colorful colors that is also used as a mask on the head and neck'. Etymology: pa'l 'for the, for' and yacatl 'nose', Daz."...pray with a bandana like a sun cloth..." "Pascuales". The voice was documented since 1796 in Oaxaca. ${ }^{5}$ Palero 'player who in connivance with the banker or carver, plays and wins by starting with him later, to bring in others who steal between the two', DMej."...and they were charged cuaco the drainers, not far..." "blanket" Pambazo "ordinary and cheap bread, of inferior flour consumed by poor people', DMej."-Two virotes, a pambazo and the birdseed..."'Idyll and elegy" Papalote "the kite or toy that is made of paper, on light rods, and that is blown away by holding it with a thin rope'. Etymology: papálotl 'butterfly'. DAz.”...in pursuit of a kite..." La Rumba. Papujado 'bulky, raised or protruding and hollow', DLE.”...Remedios, dizzy, papujadas the eyes...” La Rumba.

Parraleño 'type of bean'."...some refried parraleños with shredded cheese..." "The cooks and the daily life". Paya 'person from the countryside with few economic resources who immigrate to the city', DM."...the decent ladies pointed to her as paya." La Rumba. Pelado "skeptical person, pessimistic, without discipline, rebellious, brave and individualist of scarce education, language and obscene manners' Yáñez/DMej.”...the skin is wrapped in it while..."“The blanket" Pelotera 'zambra, lawsuit to blows', DMej."...no balls are formed in front of the balconies of a girl"“"The noises of Mexico". Pepena $r$ "pick up what is scattered on the ground'. Etim. pepena 'pick something or pick up something scattered on the floor', DAz.'Try to punish them when you break into a scream:..."“Mandatory stop 6 passengers." Pepitoria 'sweet made in pasta with pumpkin seed and marshmallow or piloncillo', DMej."...the joys and pepitorias..."“The candy" Petate 'woven mat, tule or fine palm, of very varied uses among Mexican natives, as a carpet, as a mattress, as a cover, as wrapping for 
wrapping, as a lining for boxes, as a seat or respald or for chairs etc. 'Etymology: pétlatl 'mat'. DAz."...extended sheets, wet mats and muddy guaraches." La Rumba. The voice was documented since 1694 in Oaxaca. ${ }^{5} \mathrm{Pial}$ " tie that is thrown to the legs of the animal to knock it down or catch it', DM."...no way to give it a pial"“Portfolio notes"

Pichicato 'referred to someone who is stingy, who skims too much on cats ', DM."-What pique are you..." Scientific recreations Loans. Pilmama 'the maid who carries the children, aya, babysitter'. Etim. pilli 'child' and breast 'carry or carry a thing or a person', DAz.".. until they reached the heads of the pilmamas and..."“Velocipets and bikers". Piloncillo "brown sugar that is usually sold in coneshaped or truncated-cone bread', DMej.”...i Tú, son of the plebeian piloncillo?"“The candy". Pinhuica or Pingüica 'shrub up to three meters tall, brown globose fruit, edible and sweet and sour taste'. DM."...seven pinhuicas, coffee with milk..."“Genesis of the crime". Pinacate 'apterous insect of black or dark brown color, that grows in the humid corners'. Etim. pinácatl 'large beetle', DAz.'They rush and tease an unofficial pinacate."'Make the bear." Piocha 'the pointed beard that is left on the chin'. Etymology: piochtli 'was the tuft that was left in the occiput to the boys when they cut their hair. Later it was applied only to the pointed beard ', DAz."...chivos retozones with face of English of long piocha ;..."'Gladiator". Pipiol or "name given to the youngsters up to 6 or $8 \mathrm{~d}$ and age'. Etim. pipiyolin or pipiolin 'honey bee that makes honey', DAz."...when the three pipioles, Juanillo, Pepe and Federico..."“'Del Diario de Micrós: A farewell". Pipirin 'food', DM."...and throws his blessing on the pipirin soup..."“Behind the curtain". Pirrimplina 'girl', DM. 'short person'.”...alta or pirrimplina ", From the obstacles to the evolution of territorial feminism"

Pítimo "drunk'."'Do not drink because you're already pítimo." La Rumba. Plastron "very wide tie that covers almost all the part of the front of the shirt discovered by the vest. Today out of fashion ", DMej."...coquette plastron ties (made at home)..."“Poor Jacinta!" Popote "plant of the family of grasses. It has many different uses: in bunches the stems with the flower serve as brooms or dust shakers; its hollow, clean stems are used as suction tubes to drink liquids. Etymology: pópotl 'broom,,"...and a straw fungía rifle."“"The pointer and the soldier." The voice has been documented since 1772 in Jalisco. ${ }^{5}$ Por cordillera 'to pass a thing from one person to another', DMej."...when she did not know how to drink he hurt her, so she arrived by mountain range."“The death of Pioquinto Bellido". Pulque 'very common drink in the Central Table of Mexico, transparent white color and sluggish consistency and smell a little nauseous. It results from the fermentation of maguey mead. Etymology: apócope of poliuhqui - actli 'rotten wine'“...large barrels muddy and filled with pulque."“The ancient festivals". The voice has been documented since 1525 in Mexico City. ${ }^{5}$ Pulquería 'store where pulque is sold', DMej."...Each canteen, figón, pulquería..." "The old verbenas". The voice was documented since 1731 in Mexico City. ${ }^{5}$ Pulquero 'trafficker in pulque or producer of pulque', DMej."...and almost all the pulqueros and sellers..." "The ancient festivals". The voice has been documented since 1779 in Mexico City. ${ }^{5}$

Quemador 'device of a stove, a heater, a cauldron, etc., where the flame is ignited', DEM." and the gas burners like a double row of pale stars." La Rumba. Quesadilla "corn tortilla or wheat flour folded in half, stuffed with various foods such as cheese, potatoes, mushrooms, picadillo, pork rinds, pumpkin flower, etc., cooked in comal or fried', DEM."...the turkey, the quesadilla..."'Disadvantages of the swine regime" Reata "rope of twisted fiber, used in dairy for characteristic implements of charro', DMej."...the chair scratched and burned by the rope..." "El jierro". The voice was documented in 1529 in Mexico City. ${ }^{5}$ Rebumbio 'bulla, uproar, scandal', TLEC.’The owner of El Eco del rebumbio."“The ancient verbenas" Recycling 'spice shop, store in which spices are sold and in general substances that serve to flavor the food', DMej"...Alternate with legumes in the recauderías..."“"El jugro" I collect "spices, and in general, ingredients such as chili, tomato, etc., which serve as a condiment in kitchens; vegetables that are taken daily from the market for domestic consumption ', DMej."... and the other, the basket, without the collection that was ordered." "On the plains"

Recaudería 'high-grade brandy, or liquor improved in its preparation as a beverage', DMej."... a box of cigars and three glasses of refining with..."“'On the plains" Rota "person who dresses and has middle class manners ', DEM, is popular and offensive."...I hated the elegant, the broken women who wear silk..." La Rumba. Sodería 'site where soda and soft drinks are sold ","...the soderias took away a good part of what..." The Mexico that disappears. The Concord". Soleta 'species of bi zcotela lengthened, soft, made mainly of egg and flour, very used to take ice creams or sorbets', DMej."...or until half of milk snow with soletas". "The Mexico that disappears. The Concord". Sorbete 'high top silk hat', DMej. //In Yucatan, it is 'any ice cream regardless of whether it is water or milk' (Diccionario de Español Yucateco, hereafter, DEY.),"...the new and ironed sorbets..."“The pantomime". Tabique partition, DM."The wheel of a winch buzzed behind a partition..." La Rumba. Taco "corn tortilla or wheat flour, hot and rolled with some food inside', DM."...because a day of prose cast a taco..."'Disadvantages of the swine regime". Tamal "sandwich of corn dough wrapped in totomochtle cob leaves or in leaves of banana papatla and steamed', Etymology: tamatli 'corn bread wrapped in leaves and cooked in pot', D Az."...with refried chilacos and tamales...” The old verbenas". Tamalada 'snack of tamales', DMej.”... with a tamalada after which it would be danced." Tamalera "person who makes or sells tamales', DMej."...the obese pot of the tamalera smoked..."“The ancient verbenas" Tanda "representation of popular theater, especially each one of the parts or sections in which it was divided, very usual formerly in Mexico', DEM."The other night, in the batches, there's nothing..." La Rumba. Tápalo 'chal or rebozo', DEM."...dress the petticoat and the plaid tapalito..." La Rumba. Tarugo "subject clumsy, clumsy, without malice or vivacity, foolish, mischievous, malpensed ', DMej."- Shut up, blockhead" La Rumba. Tejamanil 'wooden tablet used to roof houses or sheds'. Etymology: tlaxamanilli 'small tables or long splinters', DAz."...in clay and on a ready shingle...."Births" Tejocote 'edible fruit of the tejocote tree (Crataegus mexicanus). Etymology: texócotl 'sour, wild or hard fruit', DAz."...swallowing an infected tejocote..."“"Births" Tenate 'tanate, esportilla, cabás or soy palm, which is used to carry groceries and many other things in one's hand'. Etymology: tonatli espuerta de palma ', DAz."...the tenates full of often"“"The citizen Gestas". The voice was documented since 1796 in Oaxaca. ${ }^{5}$

Tener buen palmito 'is said of the woman with a pretty face and a slender body'."That with good heart and softness of feelings..."“The throbbing question." Tepachería 'place where tepache is sold', DM. Tepache 'fermented drink made with pineapple and sugar', DM. Doubtful etymology: tepachoa 'to apprehend or crush something with a stone', DAz."...bend of tepachería and other outlets."“"The old verbenas". In the tepache form it was documented in 1799 in Hidalgo. ${ }^{5}$ Tepalcate 'pot, case or fragment of any mud pot, pots, pots, cajetes'. Etymology: tapálcatl 'hull of broken clay pot', DAz.”...they hurriedly 
sweep crushed fruits and tepalcates, and..."“Births." The voice has been documented since 1618 in Michoacán. ${ }^{5}$ Tepetate "species of tuff or sandy conglomerate very resistant that cut in blocks is used instead of stone for the manufacture of walls'. Etymology: tepétlatl 'tosca or cuzquilla ', DAz."...A certain Aburto who traded with tepetates and alfalfa."“"Gladiator." The voice has been documented since 1813 in Hidalgo. ${ }^{5}$ Tequesquite "white salt, translucent and efflorescent that appears when the salty waters evaporate'. DNEM. Etim. tequíxquitl 'efflorescent stone', from tétl 'piedra' and quiízquitl ' sprouting ', DAz. Testeriar 'lightly touch someone or something', DM."...and with the iron (showing a fall) I tested myself here..." La Rumba.

Tianguis' market or fair of the ppblados in which goods are sold or exchanged'. Etim tianguiztli 'plaza or market' of tiamiqui 'sell or traffic', DAz."They only consumed chips in the tianguis..."'The lépero". The voice has been documented since 1525 in Mexico City. Tilica 'squalid person', DM."...fat or ticklish..."'OOf the obstacles for the evoñución of territorial feminism". Tilma " layer or blanket or cotton, wool or ixtle'. Etymology: apocalypse of tilma htli 'manta ", DNEM."...The elusive sharing the tilma that is the bridal shop."“The blanket." The voice has been documented since 1741 in Puebla." Tinacal "name given by the Indians to the departments, warehouses or pieces of the houses of the pulque haciendas where are the vats in which the mead is fermented, until it becomes pulque', DMej."...not for their tubs, but for their tinacales in the days of San Juan..."'Pane." Tinterillo "lawyer without title, and for that reason of little respect, leguleyo ", DMej."...to consult with the lawyer of the poor man, the tinterillo or the..."“Los petates" Tívoli 'garden intended for meals of men alone or poorly accompanied, political convivialities with wind and string music....and gastronomic encerronas followed by bowling, champagne, heated discussions; the tívolis do not attend respectable families but in a desperate case "definition of Micrós"' The Mexico that disappears: La Concordia". In Mexico City, it was called a garden with tree-lined promenades located in the Roma neighbourhood and it was very similar to another one of the same name that was in the Italian capital

Tlaco 'copper coin that was equivalent to half a page where that name comes from. The peso had 8 reales, the real one had 4 pages and the cuartilla 2 tlacos. Etymology: tlaco 'the half', DAz."- Tea Tlaco, Don Mauricio, good! La Rumba. Tlachique this name is applied to the tender, sweet, insufficiently fermented pulque'. Etim. chiqui (nitla) 'raer or scrape something', DAz.".. Until the fermentation in the tlachique" Electric light Asphalt and new nomenclature". Tlamapa' name given to pulque in the family language'. Etim. tlamapan 'on the sides or slopes of the mountains', DAz."...orchestra, rockets, lunch, tlamapa; guajiras..."' The thymus of the tarasca". Tlapalero 'the one who trades in tlapalería articles'. Etymology: tlapalli 'color for painting', DAz.”...Newspaper vendors and tlapaleros, I managed..."“'Judas Factory" Tocayo "person who has the same name as another', DMej." -i But tocayo !"“"The danger of the words spoken with funny accent". Tololoche "vulgar name given to the musical instrument called contrabass'. Etymology: reduplicative tololontic of tolóntic 'round thing', DAz."...a barefoot man holding a tololoche" "The ancient verbenas" Tompeate " tompiate that is the correct way. Cabás or esportilla of cylindrical shape made of woven palm very used to carry edibles'. Etymology: tompiatli ' esportilla honda made of palm'. DAz."...Between an altero of empty tompeates..." La Rumba. Torito "figure of reed in the form of a bull that has rockets attached and other fireworks that are lit while a man, who carries him on his back, chases the people in the plaza', DEM.”.. spitters of lights, rain of gold, castles and bulls"“Factory of Judas" Tortilla "food in a circular and flattened shape, to accompany the food, which is made with corn dough boiled in water with lime; it is usually cooked in a comal', DM."... wielding an omelet made from the comal"“"The death of Abelardo" Tostón "silver coins of four reales in the old monetary system', DMej."...even a tostón in tenths...”“El jierro". Totol or totole "vulgar name of the turkey, common turkey'. Etim. totollin 'chicken', DAz."...Is putting me like a totole..."“"The death of Pioquinto Bellido". Totopo "the tortilla of corn or wheat flour, well roasted'. Etim. apocope of totopóchtic, DAz."...they only consumed totopos in the tianguis..."“The lépero".

Trinquis 'drunk', DMej."...of a minor throwing trinquis..."“Da capo al signo". Tripa "hose used for watering,,"...the American güeritos water with a gut his garden..."'The private street". Trique "utensil or piece of furniture of little importance or out of use', DEM."...throughout the year in the quarter of the triques." "Births"

Tular 'place of a lagoon populated with tulles'. Etymology: tullin or tollin 'sedge or bulrush', DAz."...Singing in the tular..."“Brisas $y$ hondas" Tuna 'fruit of the nopal'. Etymology: perhaps it has a kinship with the Aztec voice tonalli ' heat of the sun, summer time', DAz."...and goes to a vendor of tunas that..." Portfolio notes" Vicentear 'vulgar and furtively see', DMej."...did not you play the boy Claudio?..." "The dangers of El Grito" Vidurria 'happy and carefree life', DM as vidorria.'I, how capable, would have given me a vidurria !" La Rumba. Voluptosear 'feel or suffer a voluptuous feeling'“... we vopulptuosía that the eleven times mother of the Council..."“Of the obstacles to the evolution of territorial feminism" Vuelto "money that is returned to the person who makes a payment with coins or bills of value higher than the amount paid', DM."...Churned cents drawer again..." La Rumba. Zacate 'grass, grass, grass'. Etymology: zácatl 'straw', DAz."...zacate in the distance with the clear stain of its silhouettes..."'Gladiator."The voice has been documented since 1620 in Guerrero.

Zalea 'skin or leather in general', DMej.'”'There was an aristocrat under his sheepskin from vulgar and street escuintle"' The death of Abelardo". Zapotazo' porrazo, costalada, hit that occurs on the floor with rumble and apparatus', DMej."...and stubborn of what they will say, to every zapotazo, which..."'Skate you?" Zempasúchil 'very common plant of the family of yellow flowers composed or synanteráceas (Tagetes erecta, Tagetes multiseta). They are commonly called flower of the dead for being used as a wreath at funerals and burials. 'Etymology: cempoalli 'twenty, in the sense of many' and xócitl 'flower', DAz"The day of the deceased over his bones there is not a humble zempasúcil..."“'Idyll and elegy"

Beside these voices that are the vehicle of the presence of characters and narrators because they are characterized by their use according to that concrete and collective verbal reality called popular norm (most of the characters) and the cultured (narrators and few characters)) are other foreign - born (clown, card, paletó, cachenez, coupe, bisteses and a dozen more, only in the narrative voices) only in certain accounts and whose use is travel product, readings and activities of 1 author, and these same causes may be those that make use of changa chanarnaar or changuear 'joke, joke', rebumbio 'relax, uproar' ripped 'poor', start 'poverty' and often 'loose coins, trash' and Puerto Rican bills 'type of fabric' and figurine 'fashion magazine' that are not typical of the popular, colloquial and cultured linguistic norms of Mexico City at present, although, perhaps, they were part of it at the end of the 19th century. 


\section{The Indigenismos}

In the Mexican dialect, the lexicon of indigenous origin has an important place in daily communication, although in the written language its presence is lower because its use depends on the peculiar preferences of the writer, the situations of the plot and especially its own idiolect that has been nurturing throughout a life of contact with his speaking community. The naming of an object, a person, an animal or an action with an indigenismo is sometimes because of a will of style of the speaker or the writer (be it the cases of totopo, turkey, pilmama or pepenar), another is due to that object, person, animal or action does not have a Hispanic synonymous (are cases of pulque, tocayo, Escuintle or chimiscolear). In Micros' prose, these situations occur freely and without a doubt they obey both to the desire to communicate their ideas in a way that is understandable to any reader in Mexico City and not in another French one, as did his contemporary Manuel Gutiérrez Nájera. ${ }^{13}$ The totality of the indigenisms that Micrós uses in his texts are extracted from the popular and colloquial speech of the capital mexicana, words that surely came to him in different ways because he certainly heard them several times or only a few or found them in some dictionary or book of indigenous subject in its eagerness to know more the past of its city. Unfortunately, we do not know the fate of his library.

And this popular and colloquial origin of its presence in chronicles and stories is supported by the study conducted by Lope Blanch ${ }^{14}$ in Mexico City in which he documents 95 indigenous voices of absolutely general knowledge, of which 37 appear in the work of Micrós. On the other hand, Lope Blanch assures, in his study, that there are 155 indigenous words of general use in Mexico, 50 of which Micrós collects in his texts. These totals are extracted from the sections absolutely general knowledge voices (95 Lope $/ 37^{4}$ Micrós), voices of knowledge $\mathrm{c}$ asi general (60 Lope $/ 13^{5}$ Micrós). The other sections show 62 Lope and $14^{6}$ Micrós: voices of average knowledge, 39 Lope and $6^{7}$ Micrós: very little known voices and 30 Lope 0 Micrós: virtually unknown voices. These data confirm that Micros reached for indigenous voices with different nuances of use at that time, but usual at last, and never from unknown voices, voices que endorsed this diachronic status in the work of Lope Blanch when it was published 60 years later of the death of our author.

However, Micrós registers 24 voices that, for some reason, do not appear in Lope Blanch's studio, and we should not consider them as unusual in Mexico since atolería, bachicha, barbacoa, bule, cacique, canoa, chilaca, chiluca, chimiscolear, chimolera, petticoat, jagüey, joloche, jicarero, maguey, mamey, pipiolo, tamalada, tamalera, tejamanil and tuna usually appear, with varying frequency, in colloquial speech throughout the Mexican geography. The three remaining: chicha, chimixtlán and Tlamapa are, to pare cer, words into disuse and are not registered das neither DM nor the DEM are dictionaries of mexicanismos emerging. There will be rigorous studies to corroborate this situation. In short, Micros documents 94

4Atole, cacao, capulín, cocol, comal, coyote, chile, chocolate, enchilada, escuintle, guaje, guajolote, guarache, huacal, jacal, jícara, matatena, rope, metate, milpa, cactus, paliacate, kite, pepenar, backpack, pilmama, popote, pulque, pulquería, pulquero, tamale, tejocote, tepachería, tlapalero, tocayo, grass, zempazúchil.

${ }^{5}$ Ajolote, ayate, chichicuilote, chinampa, chiquihuite, mayate, ocote, piocha, tepalcate, tepetate, tequesquite, tianguis, totopo.

${ }^{6} \mathrm{Cacle}$, cacomixtle, huizache, mecapalero, otate, pinacate, tenate, tilma, tinacal, tlaco, tlachique, tololoche, tompeate, tular.

${ }^{7}$ Acocote, chahuiztle, equipal, juil, neutle, totol, indigenous voices presumably in use in the late nineteenth century and early twentieth century in the City of Mexico. Most of them (64) continue to be used by Mexicans currently in both oral and written languages, the minority (27) has less use and only 3 have possibly fallen into oblivion. All of them have a particular significance from the diachronic point of view of our Mexican dialect as long as they are still valid in our daily communication.

\section{Conclusion}

If you can Micros to write"...but the empyrean, where they play very soft melodies angelic orchestra, a thousand suns illuminate the Célico stage, and souls feel the ineffable joys of eternal contemplation..."“White Soul" is also able d e register"...but on Thursday I made a message telling me that it was violent and I went. Your daughter Petra is still bad of the asidentes, she foams by the mouth..."'Portfolio notes"in a frank commitment to not follow the requirements of a decadent romanticism and to take the drops of an overarching realism, both -romanticism and realism-how skiemas of social life in the who is involved and the author develops and structured by tradition literary varied origin and by the inherited language of the house and the neighborhood of Mexico City where he grew up. In these texts is shown the daily speech of leperos, men in love, women tainted, prostitutes, self-sacrificing mothers, professors, juries, reporters and one or another dog or canary: the common people. And all speak as Mexicans contemporaries to us (except for the juries who are you and you know resemble the writings and sire of the narrator of"Historia de versos" and other stories.) These are the extremes of Micrós's records: coherent discourse, argued and even anachronistic -for the speaker of today-, of the jury that exonerated Remed ios Vena, and the other careless and loaded with immediacy of the inhabitants of the neighborhood.

Now, which of these mentioned pronunciations, syntactic turns and exposed voices are still in use today or have they changed their phonation or their forms or their meaning or have they been lost? Some of the consulted dictionaries do not contain the totality of the studied words, the works of linguistic and sociolinguistic geography contain, without a doubt, valuable samples of the popular speech and educated Mexican, and in them it is, perhaps, the answer. And we must ask ourselves still people are said probe, some people say and trapié the floor of the room, a child asks for a jaletina, a patient says after these riumas not let go me, the gun contemporary writer recreates the record: there stood majestically the cathedral, is still used mialma, memories to all of your house, do not delay please or I will do it later, then? The answers are not only in linguistic studies, but we can also get them if we observe our daily communication with friends, market people, on television and on the radio, everywhere. As for the phonetic records, I think ora, riumas, pos, Nah, haiga, supposedly, juerte, you were and suburbs are fully applicable in certain social sectors, like go, nadien, tardastes, difer i ency, julano (which they do not appear in the analyzed texts). They are speech anomalies that appear, above all, in Mexicans with precarious education (not in all but in some who have studied). Vide, trujo, afusilado, iduqué and others, perhaps, can be heard in ranches or much marginalized towns. It will be necessary to do studies on the rural Spanish Mexican to know it with certainty.

The aspect morfosintactic of voices tells tive follow fashion a bunk inherited Tura: I olfateólo, limpiólos, contábanse, could be seen, but never in the characters, because they show form as more colloquial 
expression pattern is caramel, 'the pattern is sweet as the cajeta " make pills ' little balls' (with the dry mucus), I do not like to dress from dice ' to dress with given clothes' to give a vidurria 'to give the great life', to walk whipping streets 'to walk around' they were phrases of the public domain at that time of the 19th century. Today, some have disappeared and few of those forms are still in use: then, later, to pest someone or something, I did not tell them? Andele, leverage them, send them (scant appearance in the texts), in the colloquy, Not so in formal writing.

The more than 200 voices commented, including 94 of indigenous origin, can be classified as follows:

1. Disused: action, starter, ${ }^{8}$ atorzonar, baratillo, Catalan, changuear, key, chicha, chimixtlán or chim i sclán, itamo, jeremiquear, anole, memories, parraleño by mountains, Leopoldina, voluptosear, osculizar, escolapiar, desteloscopiar, Cachote, plastron, enfullinar, escuchilla da, chicha, pipiolo, pítimo, tlamapa.

2. Usual with another meaning: ticket 'money, currency', pambazo 'bread stuffed with potatoes with sausage dipped in sauce of chile guajillo ' DM, match 'in supermarkets, young or old that helps to pack the products that have been bought' DM, chrome 'very physically attractive person' DM, lépero 'foul person, foulmouthed, rude', antrum 'tavern or discotheque where young people go' DM, tanda 'collective savings system, amount of money saved in that system' DM, 'group of alcoholic beverages that are served every time at the request of parishioners', cafre ' person who drives a car irresponsibly at high speed and without regard to the others' DM, burner 'lighter or lighter generally alcohol, recording device CD or DVD or other computer media ' DM, figurine ' very well dressed and groomed person 'DEM, action ' document representing one of the parties into which the share capital of a limited company ' DEM, jamaica ' plant flower is divided of the same name whose cooking is prepared refreshing water and tea 'DM, often 'stew caldoso with pancita cut into small pieces, corn, chile and tomato, DM, but in the Yucatan Peninsula (not in all) is still using the Canary meaning of' loose coins, trash ', rebumbio ' party of people of low socioeconomic stratum, DM, but in the Yucatan Peninsula (not in all) it is still used in the Canarian sense of 'riot, disorder', guayín 'passenger car with a space and door in the back, which sometimes is used to transport cargo ' DEM, pelotera ' gossip ' DM, tostón ' fifty cent coin, fifty units of something ' DEM, cartridge " metal tube containing gunpowder, ammunition or bullet used in firearms DEM, capirote, in the Yucatan Peninsula (not in all) is' tapa or cubierta del engine in s car', (DEY), wastrel 'rascal, loafer' D LE, sherbet in Yucatan, is 'any ice cream regardless of whether it is water or milk' (DEY), woodcock 'rest', make the bear 'make a fool'.

3. Usual: all other words are used in Mexican Spanish currently with varied vitality depending on the social group or the topic of the conversation.

Mexicanism is a word or a proper use of Spanish that is spoken in Mexico. The characteristics of our dialect are several. Company ${ }^{15}$ lists them in order to define the id entity of our speech, and of the 13 that it mentions are the ones we have studied: presence of indigenises: mat, cornpa, comal..., peculiar use of diminutives: carrerita, nadita,

${ }^{8}$ In Mexico, the Mexican Academy of Language suggested his disappearance of the DRAE (1992) as not usual, but recently I have been able to document this Canarian voice in Campeche and Mérida as a passive lexicon only. tempranito, orgullito...and duplication of possessives: his uncle to you..., which are aspects of singular presence in our Spanish, in addition to the use of later, then"with that iron it has a sense that it heats up later, then at the temperature of the body" "El jierro" If the point of focus is on the phonetic part in the characters by the presence of anomalies in phonation: pos, juerte, afusilado, pior, tantiaba, pader by pared, testerié and others, and the morfosintáctico line we also find unique uses:"---Dacha the umbrella","...Dona Maria, your partner of you.", In the lexical part, this is not so much in them because you can see that this same characters use few voices of indigenous origin Some nouns: (tlaco, bittern, cornfield, cagüixcle, cacomistle), few verbs: (bute, changuear, Enfu llinar-is and testerear) and counted adjectives: (rota and pítimo, I aguamielado 'drunk'); that is, the characterization of them as speakers of the popular norm is more evident in phonetics and morphosyntax than in the lexicon because the characterizing registers They are most abundant in est os level is language, and when compared with the current Spanish see that many phonetic forms continue to be used, morphosyntactic less safe then, then and Lexical are several voices in force at minus in the colloquium and rarely in writing. On the other hand, to characterize the different narrative voices, one must resort to morphosyntactic and lexical registers. In breasts of shirt is an expression used by the narrative voice exclusively, is a gallicism that means"in sleeves of shirt" and indirectly alludes to the quality of a man who does not have money neither to buy a vest. Academic use of certain narrators of these stories and chronicles is reflected in: He remained remedies alone...displeased girl"but with a very colloquial reef, the narrator uses" an obese matron who ranted Remedios", as a symptom of self idiolect and current use of the author. The use of diminutives gives the stories a Mexican touch because in their use it seems more important the"vision" of those who proffer them than reality itself:"...and to sharpen it and turn it into a cane or spindle..."'El jierro","...take from there a very cute jarrito, from Guadalajara..."“"El jarro","...I do not have a little dream."'If the girl knew!".

As can be seen, indigenous voices and other high use today and considered mexicanismos (omelette, cornet, lépero, drainer and many more) are the hallmark of the mixture that our author of certain lexical records, on the one hand, by the novelistic tradition (especially Fernández de Lizardi) and the cultured literature, and by the popular vein of the environment in which he grew up and which he knew well, on the other. His writing tries to show the popular Mexican Spanish, and to achieve it he not only transcribes the rustic pronunciations of the characters, his fashionable phrases and his indigenous lexicon and also of another origin (tanda, pepitoria, alegria), but he uses, both in the narrative voices as in the characters, indigenous and colloquial nuances in a lexicon understandable by any Mexican of that time, lexicon with a personal assessment given by the speaker and the reader, and which is determined by the use made of him and of the acceptance he has in his speech community, as in Argentina with verbal conjugations (look, come, Etc. $)^{16}$ or the Yucatan Peninsula with the voices (chicolear, Tulix or jichoso) and is, ultimately, the creation of an identity and own standard. In these linguistic details lies the testimonial value of the works of Micrós as they are repositories in which the daily speech of the neighborhood of Mexico City can be explored in the 19th century and compared with the current registers. The language changes with time, it is renewed daily, its use cancels or modifies some of its elements, creates new ones, and this is what determines its paths and imprints. The works of Micrós are there as chronicles of a constantly boiling dialectal modality and as irradiating foci of the identity of the Mexican. ${ }^{17-24}$ 


\section{Acknowledgments}

None.

\section{Conflicts of interest}

Author declares that there is no conflict of interest.

\section{References}

1. Sergio Fernández. Anthology of modern and contemporary novel of Mexico. Mexico: UNAM; 1975.

2. José Luis Martínez. Romantic poetry. Mexico: UNAM; 1941.

3. Lara Luis. History of the expansion of Spanish through Mexico. Nueva Revista de Filología Hispánica, México: 2008;56(2):297-362.

4. Melis Chantal, Rivero A, Arias Beatriz. Linguistic documents of New Spain. Mexico: Gulf of Mexico; UNAM; 2008.

5. Company Concepción, Melis Chantal. Historical lexicon of the Spanish of Mexico. Mexico: UNAM; 2005.

6. Company Conception. The 18th century and the linguistic identity of Mexico. Admission speech to the Mexican Academy of the Language. Mexico: UNAM/Academia Mexicana de la Lengua. 2007.

7. Lara Luis. Dictionary of the Spanish of Mexico. Mexico: The College of Mexico; 2010

8. Santamaría Francisco. Diccionario de mejicanismos. México: Porrúa; 2005 .

9. Goodman Kenneth. Glossary of Americanisms used by Rivas Larrauri in Del arrabal. Master's thesis: University of Arizona; 1964.

10. Cabrera Luis. Diccionario de aztequismos. México: Colofón; 2002.

11. Montemayor Carlos. Dictionary of Nahuatl in the Spanish of Mexico. Mexico: UNAM; 2009.
12. Fernandez de Lizardi, Jose J. The Mexican thinker. In: Agustín Yáñez, editor. México: UNAM; 1979.

13. Güemez Miguel. Dictionary of Spanish yucateco. Mexico: Plaza y Valdés; 2011.

14. Lope Blanch, Juan M. Indigenous lexicon in the Spanish of Mexico. Mexico: The College of Mexico; 1969.

15. Company Concepción. The formation of Spanish and Spanish grammar. Memories of the Mexican Academy of Language. Mexico: Mexican Academy of Language; 2011. p. 49-59.

16. Lara Luis. Historical language and normativity. Mexico: The College of Mexico; 2004.

17. Company Concepción. Dictionary of Mexicanisms. Mexico: Siglo XXI editors; 2010.

18. Corbella Dodors, Corrales C ristónal, Alvarez Maria. Lexicographical Treasury Spanish Canary Islands. Madrid: Real Spanish Academy; 1992.

19. De Campo Ángel. Lectures and notes. La Rumba. Mexico: Promociones editoriales mexicanas, SA de CV; 1979.

20. De Campo Angel. Pueblo y canto. Mexico: UNAM; 1973.

21. De Mauleón Héctor. Ángel de Campo. Mexico: Editions Cal y Arena; 2009.

22. Dictionary of Americanisms. Lima: Association of Spanish Language; 2010 .

23. Dictionary of the Spanish language. Madrid: Real Academia de la Lengua Española, Espasa Calpe; 2014.

24. María Sherwood, San Juan. Lexicographical treasure of the Spanish of Puerto Rico. Academia Puer torriqueña de la Lengua, 2016. 